\title{
Customer Value Co-Creation Behavior and Customer Loyalty: a Case Study in The Mobile Application Industry
}

\author{
Mariyudi \\ Department of Management \\ Universitas Malikussaleh \\ Aceh, Indonesia \\ mariyudi@unimal.ac.id
}

\author{
Faisal Matriadi \\ Department of Management \\ Universitas Malikussaleh \\ Aceh, Indonesia \\ faisalmatriadi@gmail.com
}

\begin{abstract}
This research analyzes the relationship between value co-creation behavior, perceived service quality, customer satisfaction and customer loyalty, using a Service-Dominant logic (SD logic) theoretical framework. Using structural equation modeling, the study examines a sample of 350 online product communities in Indonesia. The empirical analysis provides conclusive evidence that the value co-creation behavior has an influence on the perceived service quality and customer satisfaction. It also confirms that perceived service quality and customer satisfaction have an influence on customer loyalty. To ensure an effective value co-creation process, firms need to motivate their customers to participate.
\end{abstract} loyalty

Keywords - value co-creation; service quality; satisfaction;

\section{INTRODUCTION}

Some recent unpredictable changes in technology have revealed complexity in the business environment [1],[2]. However, despite the variety of choice regardless industry, companies are often struggling to create products that are appealing enough to fulfill customers' needs, therefore, increase loyalty and consequently profits [3],[4]. To achieve such level of product's success, companies have to be constantly innovative [5].

Companies have to look for resources of new ideas outside the boundaries of their firms [6],[7]. Therefore, involving target customers in a value generation process have been recently gaining its importance as a new marketing strategy [8],[9]. Such new marketing strategy, which can lead to innovation, consumer's loyalty and profitability, refers to cocreation. Consumers are seen as a key resource in the process of value creation and innovation of a company [10].

The impact of value co-creation in business activities on consumer's behavior is growing interest to both, academics and marketers. The importance of value co-creation in servicebased organizations differs from manufacturing industries [11]. The difference lies in effect associated with consumerrelated outcomes such as customer loyalty [12],[11], customer satisfaction [12],[11],[13], and firm-related outcomes such as firm performance [14] increasing technical quality and functional quality of firm's activities [10],[15] and sustainability of service organizations [16],[17].

Knowledgeable, networked, empowered consumers are no longer sheer responders to organization's created value. But rather active value creators [18],[19],[16] and therefore, understanding the business value co-creation activities between both suppliers and consumers is of great importance to research [20],[21].

There is mounting evidence showing that consumers are displeased with various market offerings. This may be caused by the inability of suppliers to meet specific consumer requirements [16]. This is evident in the increasing number of mobile application on hand-held devices that offers genuine and differentiated solutions [22]. Seeing that, there is a growing agreement that companies engaged in service business activities need to consider value co-creation to maintain relevance to consumers' needs [23].

Hence, on the theoretical significance of this study is the examination of the impact of service value co-creation impact from a customer perspective. Customer value co-creation behavior has been generally examined at the conceptual level [18] however, empirical studies examining this relationship at the service level are limited. Hence, empirical investigation of the outcome of consumer's value co-creation involving service activities adopted in this study contributes to the existing body of the knowledge on service value co-creation behavior. The purpose of this study is to investigate the impact of service value co-creation on customer loyalty in Indonesia mobile application industry.

\section{BASIC THEORY AND HYPOTHESES DEVELOPMENT}

\section{A. Co-creation behaviors in service systems}

Value co-creation is fundamentally a relational perspective that emphasizes contextual frames within which the enmeshed consumers participate in core behaviors to use resources for mutual benefits [24],[18]. The latter is also referred to as resource integration, representing in this case consumer efforts in interacting with and using resources to improve their wellbeing [25]. 
Thus, such participation behaviors are key task-related activities that enable the customers to fulfill their fundamental behavioral responsibilities in service exchanges. In line with [25],[18] and [26], refers to such core task behaviors as in service co-creation behaviors. It further defines them as customers participation in, and contribution to, task-related resource integrations that manifest their effectiveness in a service system.

Value co-creation behavior is a means by which customers interact with others so as to adjust to a specific environment and orchestrate resources in a service system. A service system is an arrangement of resources connected to other systems by value propositions [27]. Recently, [18] proposed a comprehensive concept of value co-creation behavior (VCB) that encompasses a variety of consumer behaviors, which comprises participation behavior and citizenship behavior.

\section{B. Perceived quality}

Many researchers have developed the study of a broad concept of quality which focuses on the integration of different disciplines [28]. However, in previous research, quality has not been given a universal definition [29],[30],[31]. Service Quality is defined as the consumer's judgment about a service providers overall level of excellence [32].

Perceived value is the inclusive judgment about the balance between what is rewarded and what is sacrificed during customer consumption experience, and Customer value focuses on both perceived monetary and non-monetary price [33]. Customers create value from their relationships and networks, and they take on the important role of value actualization as value co-creator. Also, [34] point out that the creation of relational value is a significant factor that affects customer satisfaction.

Perceived quality is one of the most significant factors that affect customer satisfaction and behavior intention [35],[36],[37] and many researchers have studied the relationship between perceived quality and satisfaction [29]. In the field of service industry, the importance of perceived quality as relates to the service provider's success or failure has been well studied [38],[39],[40],[35]. Customer commitment to a service is a key to customer retention, thus, customer commitment and loyalty has been actively studied as one of an important concept in the business field [41]. Previous research have established that perceived quality is the antecedent of both customer loyalty and behavior intention [41],[35].

\section{Customer satisfaction}

Satisfaction is defined as an evaluation of the surprise inherent in a product acquisition and/or consumption experience [42]. In other words, the definition of satisfaction is a consumer's "pleasurable fulfillment" generated from the consumption experience [43],[44]. In addition, service satisfaction is defined as satisfaction with performance is a post-consumption evaluation of perceived quality relative to pre-purchase performance expectations about quality [45].
Even though both constructs are measured using an expectancy-disconfirmation paradigm, these two concepts are clearly separated according to the subject. Service quality is the degree to which perceived performance conforms to prior expectations. In contrast, satisfaction is an emotionally based response: pleasure and displeasure. Many previous studies have actively examined the relationship between customer satisfaction, service quality, and purchase intention. Service quality is an antecedent of customer satisfaction [46],[47],[35],[36], [48].

\section{Customer loyalty}

Brand loyalty, the customer's conscious or unconscious decision, to repurchase the brand continually, has been one of the most discussed marketing concepts in the past decades [49]. This is not surprising since the crucial factor for the survival of a company is retaining current customers and making them loyal to the brand [50].

According to [43], for a long time, client's satisfaction was the main strategic business goal. Later on, a shift in strategic business goal was done in favor of customer loyalty, criticizing the fact that satisfaction and loyalty are linked inextricably [51],[52],[53]. Moreover, brand loyalty was in the past based only on repeat purchasing, which is nowadays no longer a sufficient indicator of loyalty [52].

Loyalty, in the concept of branding, is one of the most widely interpreted concepts in the marketing literature [54]. There are many definitions of brand loyalty, but majority describe a process, revealing what a customer does to become loyal [43]. In the broader meaning, loyalty is a repeat purchasing frequency of the same brand [55]. According to [56], brand loyalty, which is a measure of the attachment that a customer has to a certain brand, shows how likely a customer switches to another brand when there is a brand's product price or features change.

To sum up previous definitions [43] postulates the following: loyalty is described here as a deeply held commitment to re-buy or re-patronize a preferred product/service consistently in the future, thereby causing same repetitive brand or the same brand set purchasing, despite situational influences and marketing efforts having the potential to cause switching behavior.

According to [43], there are four loyalty phases starting with a cognitive loyalty and continuing with affective, conative, and finally behavioral loyalty, which implies that attitudinal loyalty leads to behavioral loyalty.

From the above discussions, the following hypothesis is proposed:

H1: Value co-creation behavior positively influences perceived service quality.

H2: Value co-creation behavior positively influences customer satisfaction.

H3: Value co-creation behavior positively influences customer loyalty.

H4: Perceived service quality positively influences customer satisfaction. 
H5: Perceived service quality positively influences customer loyalty.

H6: Customer satisfaction positively influences customer loyalty.
Thus, the conceptual model of customer loyalty in the mobile application industry setting with its respective hypothesis is represented in Figure 1.

Fig. 1. Conceptual model

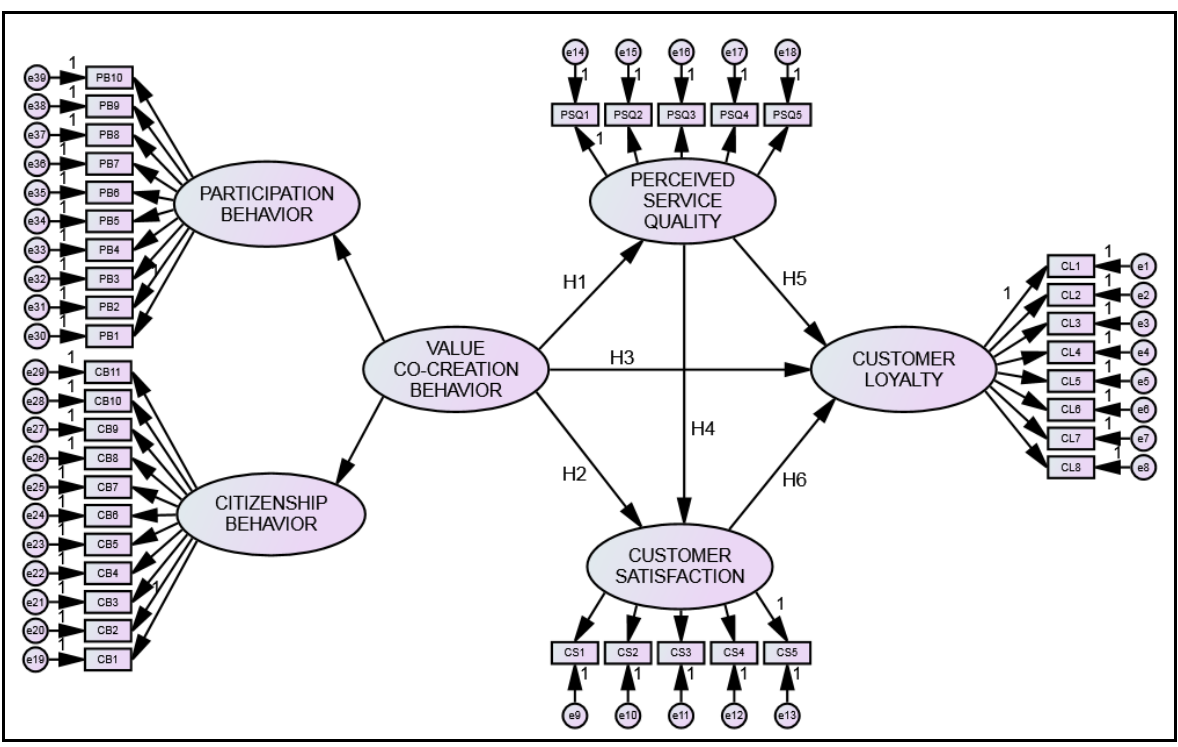

\section{METHODOLOGY}

A quantitative online survey method was used to collect data. The single questionnaire contains two sets of data for examining the models developed. This is a single method research project. The survey method is adapted and guided by the questionnaire development process proposed by [57], that accommodates a survey with multiple objectives.

\section{A. Procedure and sample}

A web-based online survey has the advantages of being interactive, convenient, and accessible [58]. Because of the research context (i.e., convergent mobile online servicesCMOS), this research study used a web-based survey where respondents could access questions through a web browser either from a PC or a mobile device. In this research, the targeted participants were CMOS users; they had a broadband connection at the premises where they accessed the survey or $3 \mathrm{G}$ access on their mobile phones.

In this research, the target population was online communities and the sampling frame were CMOS users who participate in online communities. Non-probability judgemental sampling and convenience sampling techniques were adopted [59].

\section{B. Sample selection}

Items to measure the variables in the conceptual model were developed using results found in the literature review.
For this study, the Sampling Error Formula [60] is applied to set the required sample number to support the reliability of the study. Using this formula, four variables are considered. Applying the proportion of the sample (5 point scale, 20/80), the tolerated sampling error $(\alpha=0.05)$, and the identified confidence interval (95\%), the result of the suggested ideal sample size is around 350 .

\section{Analysis}

Structural Equation Modeling (SEM) were chosen to analyze the data collected. Statistical calculations using SPSS and AMOS enabled further analyzes. SPSS is used to administer and analyze the collected quantitative data [57]. AMOS, on the other hand, is a Structural Equation Modeling (SEM) computer package employed for confirmatory factor analysis and structural analysis [57]. SEM was used to investigate impacts and relationships between testing variables.

\section{RESULTS AND DISCUSSION}

The sample in the study was collected mainly from online product communities. The sample consisted of respondents aged over 18 years old. There was a large male sample of 273 compared to a small female sample of 24 . The majority of respondents achieved an undergraduate degree qualification $(42.58 \%)$ and there were 61.62 single percentage respondents and 37.04 percent married respondents, while others were 1.35 percent. 
TABLE I. DEMOGRAPHIC CHARACTERISTICS

\begin{tabular}{|l|c|c|}
\hline \multicolumn{1}{|c|}{ Characteristics variables } & Frequency & Percentage \\
\hline Gender & & \\
\hline Male & 273 & 91.92 \\
\hline Female & 24 & 8.08 \\
\hline Educational level & & \\
\hline Primary & 0 & 0 \\
\hline Secondary & 16 & 5.16 \\
\hline College (Certificate/Diploma) & 95 & 30.65 \\
\hline Undergraduate Degree & 132 & 42.58 \\
\hline Postgraduate degree (Master/PhD) & 54 & 17.42 \\
\hline Age & & \\
\hline 18-25 & 102 & 34.34 \\
\hline $26-35$ & 78 & 26.26 \\
\hline $36-45$ & 71 & 23.91 \\
\hline $46-55$ & 28 & 9.43 \\
\hline $56-65$ & 16 & 5.39 \\
\hline Above 65 & 2 & 0.67 \\
\hline Marital status & & \\
\hline Single & 183 & 61.62 \\
\hline Married & 110 & 37.04 \\
\hline Other & 4 & 1.35 \\
\hline & $\mathbf{2 9 7}$ & $\mathbf{1 0 0}$ \\
\hline
\end{tabular}

exhibit any nonlinear patterns. Thus, this will ensure that the overall equation is linear [62].

\section{A. Data screening analysis}

There were a total of 26 questionnaires, which were eliminated due to the outliers. Deletion of cases that are outliers may also contribute to multivariate normality [61]. A total of 350 questionnaires were collected according to the sampling frame of the study. After eliminating 27 questionnaires, which were incomplete and another 26 questionnaires due to the outliers, a total of 297 samples for analysis were left.

After the transformation, all the data fell within the range of normality assumption. Nevertheless, after the skewness transformation, the kurtosis index for the data in this study fell between -1 to -6 , which is within acceptable value [62].

From the observation of each item of the respective constructs based on transformed data, the results do not

\section{B. Data analysis}

The reliability of the data is evaluated through coefficient alpha and composite reliability. The Cronbach alphas for all the constructs of the study range from 0.91 to 0.97 . A Cronbach alpha value of 0.70 and above is generally accepted to demonstrate a high level of homogeneity with the scale [63]. Hence, the measures of this study are considered reliable and consistent.

Likewise, the composite reliability for all the constructs of the study range from 0.91 to 0.98 . A composite reliability value of 0.70 and above is generally the accepted norm [63].

The factor loading indicates that all the items in the respective constructs fall above the recommended value. It ranges from 0.731 to 0.993 . The factor loading above 0.50 can be considered as a good factor loading. [62].

TABLE II. RELIABILITY OF NORMALIZED VARIABLES

\begin{tabular}{|l|c|c|c|}
\hline \multicolumn{1}{|c|}{ Construct } & No of items & Cronbach alpha & Composite Reliability \\
\hline Participation Behavior & 10 & 0.91 & 0.92 \\
\hline Citizenship Behavior & 11 & 0.95 & 0.91 \\
\hline Perceived Value Quality & 5 & 0.96 & 0.96 \\
\hline Customer Satisfaction & 5 & 0.97 & 0.98 \\
\hline Customer Loyalty & 8 & 0.95 & 0.95 \\
\hline
\end{tabular}

The correlation estimates construct value less than 0.80 indicates the absence of multicollinearity existence [62]. Thus, the constructs can be said to be distinct from each other.

The discriminant validity is measured by average variance extracted (AVE) in pairs of all constructs. Discriminant validity exists when AVE is greater than the correlation square between pairs of factors [64]. The results show that all the values in AVE are greater than correlation squares. Thus, the constructs can be said to be unique from each other or to show the absence of multicollinearity. 


\section{Structural model}

The structure model indicates that the results fall within the recommended tolerance levels. The absolute fit indices of
GFI (0.947) and the RMSEA (0.015) indicate a good fit. The incremental fit indices of AGFI (0.926), TLI (0.964), and CFI $(0.965)$ also indicate a good fit.

TABLE III. COMPARISONS OF GOODNESS-OF-FIT INDICES OF SEM MODELS

\begin{tabular}{|l|c|c|}
\hline \multicolumn{1}{|c|}{ GOF Indices } & Criterion Guidelines & SEM Results \\
\hline Chi-square $\left(\chi^{2}\right)$ & & \\
\hline Chi-square & & 441.372 \\
\hline Probability & $\mathrm{p}>0.05$ (Jöreskog and Sörbom 1992) & 1.027 \\
\hline Absolute fit measures & & \\
\hline GFI & $>0.80$ (MacCallum and Hong 1997) & 0.947 \\
\hline RMSEA & $<0.10$ (Steiger 1990) & 0.015 \\
\hline Normed chi-square & $<3$ (Hair et al. 2010) & 1.984 \\
\hline Incremental fit measures & & 0.964 \\
\hline TLI & $>0.90$ (Gerbing and Anderson 1992) & 0.965 \\
\hline CFI & & \\
\hline Parsimony fit measurement & $>0.80$ (MacCallum and Hong 1997) & 0.926 \\
\hline AGFI & & \\
\hline
\end{tabular}

\section{Hypotheses testing}

According to the SEM, the model is confirmed. The tests of the hypotheses shown in Table 4 . The standardized estimate (ß) of the path between the Value co-creation behavior and perceived service quality (0.609), Value co-creation behavior and customer satisfaction (0.192), Perceived service quality and customer satisfaction (0.158), Perceived service quality and customer loyalty (0.478), and Customer satisfaction and customer loyalty (0.758) were significant. Therefore, Hypothesis 1, 2, 3, 5, and 6 were supported. While hypotheses 4 is not supported.

TABLE IV. TESTING THE HYPOTHESES OF THE STRUCTURAL RESEARCH MODEL

\begin{tabular}{|c|c|c|c|c|}
\hline Hypothesized Path & $\begin{array}{c}\text { Std. Reg. } \\
\text { Weight }\end{array}$ & $\begin{array}{c}\text { Critical } \\
\text { Ratio }\end{array}$ & Significance & Hypothesis \\
\hline H2: Value co-creation behavior $\rightarrow$ Customer satisfaction & 0.192 & 4.360 & 0.000 & Supported \\
\hline H4: Perceived service quality $\rightarrow$ Customer satisfaction & 0.158 & 2.837 & 0.005 & Supported \\
\hline H5: Perceived service quality $\rightarrow$ Customer loyalty & 0.478 & 9.295 & 0.000 & Supported \\
\hline
\end{tabular}

The results have changed the conceptual model to a SEM model, which is presented in Figure 2.

Fig. 2. SEM model

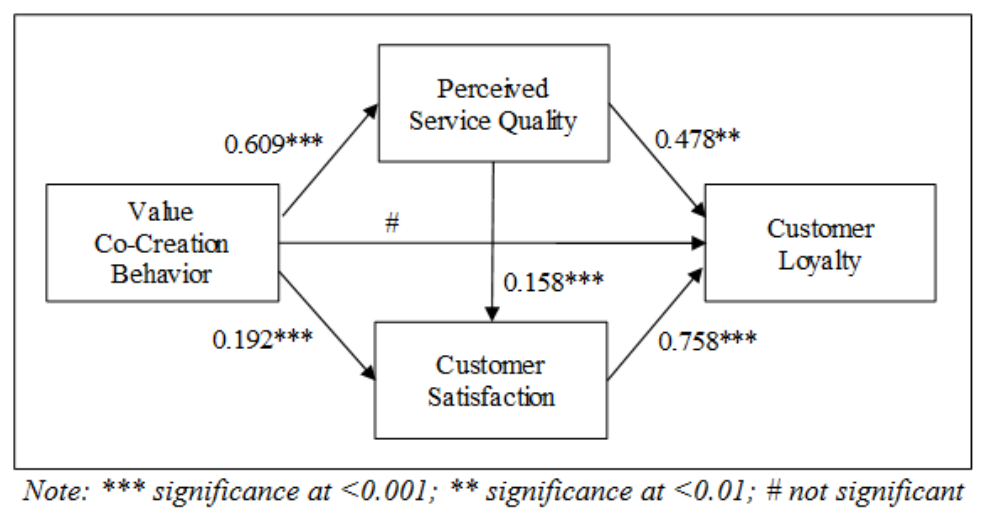




\section{Discussion}

The results of this study show that the value co-creation behavior is a direct path and is a factor that significantly affects the perceived service quality and customer satisfaction. The finding supports $\mathrm{H} 1$ and $\mathrm{H} 2$, meaning a consistent finding with previous research studies [27],[34],[25],[18],[26].

Moreover, the result of data analysis shows that perceived service quality has a positive effect on customer satisfaction and customer loyalty. The finding supports $\mathrm{H} 4$ and $\mathrm{H} 5$, meaning a consistent finding with previous research studies [33],[34],[35],[36],[37],[29],[38],[39],[40].

Additionally, data analysis supports earlier findings that customer satisfaction have a positive effect on the customer loyalty. As such, managerial awareness of such impact is not only essential but also vital to profitability and loyalty matters.

Like the results of research model, it was seen that good service quality can lead to positive customer satisfaction and customer loyalty, and customer's perceived quality make a stronger impact on customer satisfaction than on customer loyalty. It was also seen that higher customer satisfaction leads to higher customer loyalty.

\section{CONCLUSION}

To ensure an effective value co-creation process, firms need to motivate their customers to participate. For customers with higher collectivism and power distance value orientations, more effort is required to help them visualize the economic value of their participation. Customers who perceive the relationship as durable should be more motivated to make the most of their co-creation opportunities. Facilitating the creation of relational values enhances the benefits of value cocreation behavior and produces a competitive advantage.

Because participants were predominantly Samsung users, this may be explained by participants' gratitude toward Samsung which is renowned for gaining high loyalty and satisfaction from its customers. In this case, similar to having long-term relationships with friends and online acquaintances, more competent consumers who have a long-term relationship with the firm and are likely to become working consumers.

Finally, this finding suggests that consumers voluntarily share their experiences with other consumers. It supports that theory that User Experience Sharing behavior is to be considered as a consumer initiated value co-creation behavior and that consumers can be service providers. The empirical evidence not only supports User Experience Sharing and CoCreative Consumers but also confirms that Theory of Planned Behavior (TPB) framework are compatible theories with Service-Dominant (SD) logic.

To enable firm-customer value co-creation, the results of this study indicate that firms who want to co-create value with consumers should place their focus on facilitating consumers' fulfillment of needs rather than exploitation of harnessing consumers' use innovativeness. Managers should facilitate cocreative consumers' engagement through creating channels and opportunities for nurturing and communicating value initiation opportunities.

\section{LIMITATIONS AND FUTURE RESEARCH}

The sampling frame in this research is CMOS users who participate in online communities. As the data was collected from online forums, these results are subject to the limitation that all users who are members of the online community are potentially more likely to share, compared to those who do not use online communities.

The findings are limited by the scope of the research including costs and time. In future studies, offline communities and other online communities (e.g., brand communities, online gaming communities, non-profit communities, open innovation communities, social networking communities, and second life, etc.) can be used to enhance the generalisability of the two proposed theoretical models.

\section{REFERENCES}

[1] Tsafarakis S, Grigoroudis E, Matsatsinis N (2011). Consumer choice behavior and new product development: An integrated market simulation approach. The Journal of the Operational Research Society 62(7): 1253-1267.

[2] Filieri $R$ (2013) Consumer co-creation and new product development: A case study in the food industry. Marketing Intelligence \& Planning 31(1): 40-53.

[3] Epp AM, Price LL (2011) Designing solutions around consumer network identity goals. Journal of Marketing 75(2): 36-54.

[4] Ulaga W, Reinartz WJ (2011) Hybrid offerings: how manufacturing firms combine goods and services successfully. Journal of Marketing 75(6): 5-23.

[5] Cooper RG (2000) Doing it right: winning with new products. IVEY Business Journal 64(6): 54-60.

[6] Chesbrough H (2003) Open innovation: The new imperative for creating and profiting from technology. Boston: Harvard Business School Press.

[7] Ramaswamy V, Gouillart F (2010) The power of co-creation. New York: Free Press

[8] Rossi C (2011) Online consumer communities, collaborative learning, and innovation. Measuring Business Excellence 15(3): 46-62.

[9] Zhang $X$, Chen $R$ (2008) Examining the mechanism of the value co-creation with customers. International Journal of Production Economics 116(2): 242-250.

[10] Grönroos C (2008) Service logic revisited: who creates value? And who cocreates? European Business Review 40(4): 298-314.

[11] Hsiao C, Lee Y-H, Chen W-J (2015) The effect of servant leadership on customer value co-creation: A cross-level analysis of key mediating roles. Tourism Management 49: 45-57

[12] Grissemann US, Stokburger-Sauer NE (2012) Customer cocreation of travel services: The role of company support and customer satisfaction with the co-creation performance. Tourism Management 33(6): 1483-1492.

[13] Vega-Vazquez M, Ángeles Revilla-Camacho M, J. Cossío-Silva F (2013) The value co-creation process as a determinant of customer satisfaction. Management Decision 51(10): 1945-1953.

[14] Hoyer WD, Chandy R, Dorotic M, Krafft M, Singh SS (2010) Consumer cocreation in new product development. Journal of Service Research 13(3): 283-296.

[15] Zhao J, Wang T, Fan X (2015) Patient value co-creation in online health communities: Social identity effects on customer knowledge contributions and membership continuance intentions in online health communities. Journal of Service Management 26(1): 72-96. 
[16] Prahalad CK, Ramaswamy V (2004) Co-creation experiences: The next practice in value creation. Journal of interactive marketing 18(3): 5-14

[17] Vega-Vazquez M, Ángeles Revilla-Camacho M, J. Cossío-Silva F (2013) The value co-creation process as a determinant of customer satisfaction. Management Decision 51(10): 1945-1953

[18] Yi Y, Gong T (2013) Customer value co-creation behavior: Scale development and validation. Journal of Business Research 66(9): 1279-1284

[19] Xie C, Bagozzi RP, Troye SV (2008) Trying to prosume: toward a theory of consumers as co-creators of value. Journal of the academy of marketing science 36(1): 109-122

[20] Verhoef PC, Reinartz WJ, Krafft M (2010) Customer engagement as a new perspective in customer management. Journal of Service Research 13(3): 247-252

[21] Shaw G, Bailey A, Williams A (2011) Aspects of service-dominant logic and its implications for tourism management: Examples from the hotel industry. Tourism Management 32(2): 207-214

[22] Theil P, Masters B (2014) Zero to one: Notes on startups, or how to build the future. 1st edn. Crown Business

[23] Lambert, Douglas M, Matias G Enz (2012) Managing and measuring value co-creation in business-to-business relationships. Journal of Marketing Management 28(13-14): 15881625.

[24] Vargo SL, Lusch RF (2011) It's all B2B and beyond: toward a systems perspective of the market. Industrial Marketing Management 40(2): 181-7

[25] Sweeney J, Tracey D, McColl-Kennedy J (2015) Customer effort in value co-creation activities: improving quality of life and behavioral intentions of health care. Journal of Service Research 1-18. Doi:1094670515572128

[26] Griffin M, Neal A, Parker S (2007) A new model of work role performance: positive behavior in uncertain and interdependent contexts. The Academy of Management Journal 50(2): 327-347

[27] Spohrer J, Maglio PP, Bailey J, Gruhl D (2007) Steps toward a science of service systems. Computer 40(1): 71-77.

[28] Boakye KG, Kwon J, Blankson C, Prybutok VR (2012) The attraction of the sizzle: A service investment model. The Quality Management Journal 19(4): 24

[29] Golder PN, Mitra D, Moorman C (2012) What is quality? an integrative framework of processes and states. Journal of Marketing Volume 76 (July 2012): 1-23

[30] Karmarkar US, Pitbladdo R (1995) Service markets and competition. Journal of Operations Management 12(3): 397-411

[31] Garvin DA (1984) What does "product quality" really mean. Sloan management review 26(1)

[32] Parasuraman A, Zeitham VA, Berry LL (1988) Servqual. Journal of retailing 64(1): 12-37

[33] Zeithaml VA, Bitner MJ, Gremler DD (2006) Services marketing: integrating customer focus across the firm 4th ed, McGraw-Hill Higher Education, New York.

[34] Chan KW, Yim CKB, Lam SK (2010) Is customer participation in value creation a double-edged sword? Evidence from professional financial services across cultures. Journal of Marketing 74(3): 48-64

[35] Qin H, Prybutok VR (2013) A quantitative model for patient behavioral decisions in the urgent care industry. Socio-Economic Planning Sciences 47(1): 50-64

[36] Qin H, Prybutok VR, Peak DA, Boakye KG (2014) UCPERF: An urgent care patient satisfaction instrument. The Quality Management Journal 21(3): 11-25

[37] ZeithamI VA (2000) Service quality, profitability, and the economic worth of customers: what we know and what we need to learn. Journal of the academy of marketing science 28(1): 67-85

[38] Choi KS, Cho WH, Lee S, Lee H, Kim C (2004) The relationships among quality, value, satisfaction and behavioral intention in health care provider choice: A South Korean study. Journal of Business Research 57(8): 913-921.

[39] Gooding SK (1995) Quality, sacrifice, and value in hospital choice. Journal of Health Care Marketing, 15(4): 24

[40] Headley DE, Miller SJ (1993) Measuring service quality and its relationship to future consumer behavior. Journal of Health Care Marketing 13(4)

[41] Moliner MA (2009) Loyalty, perceived value and relationship quality in healthcare services. Journal of service management 20(1): 76-97

[42] Oliver RL (1981) Measurement and evaluation of satisfaction processes in retail settings. Journal of retailing 57(3): 25-48

[43] Oliver RL (1999) Whence consumer loyalty? Journal of Marketing 63(4): 33-44

[44] Westbrook RA, Oliver RL (1991) The dimensionality of consumption emotion patterns and consumer satisfaction. Journal of consumer research 18(1): 84

[45] Homburg C, Koschate N, Hoyer WD (2005) Do satisfied customers really pay more? A study of the relationship between customer satisfaction and willingness to pay. Journal of Marketing 69(2): 84-96

[46] Bitner MJ, Hubbert AR (1994) Encounter satisfaction versus overall satisfaction versus quality. Service quality: New directions in theory and practice 72-94

[47] Cronin Jr JJ, Brady MK, Hult GTM (2000) Assessing the effects of quality, value, and customer satisfaction on consumer behavioral intentions in service environments. Journal of retailing 76(2): 193-218

[48] Ryu K, Lee HR, Gon Kim W (2012) The influence of the quality of the physical environment, food, and service on restaurant image, customer perceived value, customer satisfaction, and behavioral intentions. International Journal of Contemporary Hospitality Management 24(2): 200-223

[49] Khan BM (2009) Consumers and their brands: deciphering dimensions of loyalty. International Journal of Business Insights \& Transformation 2(1): 84-92.

[50] Mellens M, Dekimpe MG, Steenkamp J-BEM (1996) A review of brand-loyalty measures in marketing. Tijdschrift voor Economie en Management XLI(4): 507-533

[51] Stewart TA (1997) A satisfied customer isn't enough. Fortune 136(21): 112-113.

[52] Reichheld FF (2003) The only number you need to grow. Harvard Business Review 81(12): 46-55

[53] Jones TO, Sasser WE (1995) Why satisfied customers defect. Harvard Business Review 73(6): 88.

[54] Morgan RP (2000) A consumer-oriented framework of brand equity and loyalty. Journal of the Market Research Society 42(1): 65-78.

[55] Tellis GJ (1988) Advertising exposure, loyalty, and brand purchase: A two-stage model of choice. JMR, Journal of Marketing Research 25(2): 134.

[56] Aaker DA (1991) Managing brand equity: capitalizing on the value of a brand name. New York: The Free Press.

[57] Hair JF, Money AH, Samouel P, Page M (2007) Research methods for business. Chichester: John Wiley and Sons Ltd.

[58] Fielding NG, Lee RM, Blank G (2008) The handbook of online research methods. Thousand Oaks, CA: Sage.

[59] Malhotra NK, Hall J, Shaw M, Oppenheim P (2004) Essentials of marketing research: An applied orientation. Frenchs Forest, N.S.W.: Pearson.

[60] Fink A, Kosecoff $J$ (2005) How to conduct surveys: A step by step guide (3rd ed). Beverly Hills, CA: Sage

[61] Kline RB (2005) Principles and practice of structural equation modeling (2nd ed). New York: The Guilford Press

[62] Hair JJ, Black WC, Babin BJ, Anderson RT, Tatham RL (2006) Multivariate data analysis (6th ed.). Upper Saddle River: Prentice Hall. 
[63] Nunnally JC (1978) Psychometric theory (2nd ed) New York: McGraw-Hill
[64] Fornell C, Larcker DF (1981) Evaluating structural equation models with unobserved variables and measurement error. Journal of Marketing Research 18: 39-50. 